University of Texas Rio Grande Valley

ScholarWorks @ UTRGV

6-18-2018

\title{
Site Formation Processes of Submerged Shipwrecks. MATTHEW \\ E. KEITH (Editor), 2016. University Press of Florida, Gainesville. Xi 276 Pp. \$79.95 (Hardcover), ISBN 978-0-8130-6162-7
}

Russell K. Skowronek

The University of Texas Rio Grande Valley, russell.skowronek@utrgv.edu

Follow this and additional works at: https://scholarworks.utrgv.edu/hist_fac

Part of the Classical Archaeology and Art History Commons, and the History Commons

\section{Recommended Citation}

Skowronek, Russell K. "Site Formation Processes of Submerged Shipwrecks. MATTHEW E. KEITH (Editor), 2016. University Press of Florida, Gainesville. Xi 276 Pp. \$79.95 (Hardcover), ISBN 978-0-8130-6162-7." American Antiquity, vol. 83, no. 3, 2018, pp. 570-571., doi:10.1017/aaq.2018.30.

This Book Review is brought to you for free and open access by the College of Liberal Arts at ScholarWorks @ UTRGV. It has been accepted for inclusion in History Faculty Publications and Presentations by an authorized administrator of ScholarWorks @ UTRGV. For more information, please contact justin.white@utrgv.edu, william.flores01@utrgv.edu. 
material. If we can no longer assume a unified set of Hopewellian ontologies, how are we to explain the Hopewell phenomenon?

Several of the chapters in this collection feel like the beginnings of fruitful new avenues of research. Peter Whitridge describes his contribution on dogs in the Arctic as a "tentative first step in thinking about the ontological divide between a diverse group of humans and a diverse group of non-human animals" (p. 33). Likewise, Halperin's contribution seems to be an example of working through some interesting ideas for a recently excavated group of sites and materials. At several junctures I felt that greater dialogue with the metaphysical ontological discussions taking place in Europe might have lent extra heft to these mostly anthropologically derived debates. This is not to decry what is an impressive collection of essays, which will be an important touchstone for ontologically minded researchers on either side of the Atlantic. The provisional nature of some of the discussions in this collection should not be viewed as evidence of a lack of confidence in the material. Instead it signals an eagerness to tackle challenging new paths for research. From the evidence of this book I suspect that the future of American archaeology and anthropology will be moving toward a greater focus on questions of an ontological character; this book acts as a signpost and way-marker for this important new direction.

Site Formation Processes of Submerged Shipwrecks. MATTHEW E. KEITH (editor), 2016. University Press of Florida, Gainesville. xi +276 pp. $\$ 79.95$ (hardcover), ISBN 978-0-8130-6162-7.

Reviewed by Russell K. Skowronek, University of Texas Rio Grande Valley

Site Formation Processes of Submerged Shipwrecks explores the physical and cultural processes affecting shipwreck sites. Authors from archaeology, chemistry, oceanography, and sediment dynamics share their expertise regarding the factors that influence the formation and preservation of shipwreck sites. These include the material aspects of ships, the underwater environment, and events including storms, chemical reactions, and subsequent human activity.

In the introduction, the volume's editor, Matthew Keith, and Ian Oxley note that underwater archaeologists have recognized the importance of understanding the processes affecting site formation since the 1960s. In the 1970s and 1980s, when terrestrial archaeologists were embracing Michael Schiffer's (Formation Processes of the Archaeological Record, 1987) observations on how cultural and natural transforma- tions affect land sites, Keith Muckelroy (Maritime Archaeology, 1978) was developing models for the evolution of a shipwreck site. He recognized two mechanisms-scrambling processes and extracting filters - that would explain site condition. These, of course, have been refined over the past 40 years. This book is divided into "Natural Processes," "Cultural Processes," and "Site Formation and Heritage Management."

"Coastal and Inland Geologic and Geomorphic Processes," by Ben Ford, Carrie Sowden, Katherine Farnsworth, and M. Scott Harris, considers how sediment characteristics and movement, bottom topography, wave and ice erosion, and humans affect geomorphic processes by changing sediment transport in rivers and along coasts through damming, dredging, and the construction of groins. Two case studies, one in Oklahoma and another in Lake Ontario, illustrate their findings.

Matthew Keith and Amanda Evans contribute "Sediment and Site Formation in the Marine Environment." They consider sediment types encountered in the open ocean and the factors influencing sediment deposition, accretion, scour, and stability. They note that radioisotope analysis provides information on sediment accretion and erosion rates on wrecks.

Scour occurs when sediments erode due to waves, tides, or changes in riverine discharge. In "Marine Scour of Cohesionless Sediments," authors Rory Quinn, Robin Saunders, Ruth Plets, Kieran Westley, and Justin Dix note that different scour patterns result based on the orientation of a wreck to currents. Excellent seafloor images demonstrate their observations.

Chemist Ian Macleod proffers "Corrosion Products and Site Formation Processes." He notes that there is a fall in corrosion rate with increasing depth and an increase in corrosion rate with acidity. Warmer waters result in thicker layers of concretion. Macleod finds that the growth rate of marine organisms on iron artifacts is twice that found on bricks, stone, or ceramics.

David Gregory contributes "Degradation of Wood." In addition to Teredo navalis and other wood borers, Gregory discusses the effects of microbial decay, rot, and tunneling and erosion bacteria on wood. He notes that analysis of wooden artifacts may reveal repeated burial and exposure following sinking.

Amanda Evans and Antony Firth consider cultural processes in "Anthropogenic Impacts of Development-Led Archaeology in an Offshore Context." They find that oil and gas rigs, wind turbines, dredging, and pipeline and cable installation damage sites.

Michael Brennan's “Quantifying Impacts of Trawling to Shipwrecks" finds that fishing nets snag and 
damage ships. Photographs of damaged sites underscore his findings. Brennan feels that fishing gear is one of the greatest threats to underwater cultural heritage.

Martin Gibbs and Brad Duncan's "Cultural Site Formation Processes Affecting Shipwrecks and Shipping Mishap Sites" considers salvage as a site formation process. They note that researchers should note the distinction between "pre-impact actions" and "Crisis," "Survivor," "Systematic," and "Opportunistic" salvage and the purposeful abandonment of vessels.

Part III focuses on site formation and heritage management. Ian Oxley describes how English Heritage uses wreck site information and site formation theory to develop policies for historic marine environments. Standardization in reporting was imperative to the creation of its National Heritage Protection Plan, which determines priorities based on research and creates a framework for management.

The "DeepWrecks Project" in the Gulf of Mexico ends the book. Daniel Warren's “Acoustic Positioning and Site Formation on Deep-Water World War II Shipwrecks in the Gulf of Mexico" demonstrates how acoustic positioning data are important to determining site distributions. Robert Church's "The U-166 and Robert E. Lee Battlefield: The Equation of Site Distribution" builds on Warren's data to understand the battle and the sinking of both vessels. From this methodology, sites may be more clearly delineated and protected.

Matthew Keith ends noting that site formation studies provide information for archaeologists and heritage managers. The multidisciplinary approach demonstrates the complexity of underwater research and underscores the need for specialization.

Keith has brought together an informative volume. The discussions are nuanced and sophisticated. The target audiences of Submerged Shipwrecks are advanced undergraduates, graduate students, and professionals. All will appreciate this fine book.

Investigating the Ordinary: Everyday Matters in Southeast Archaeology. SARAH E. PRICE and PHILIP J. CARR (editors), 2018. University of Florida Press, Gainesville. xii +278 pp. $\$ 84.95$ (hardcover), ISBN 978-1-68340-021-9.

Reviewed by Lynne P. Sullivan, University of Tennessee

Interpretation of everyday life in the past is a task more often associated with museum educators or historic site interpreters than "real" archaeologists.
This innovative book challenges that perception and convincingly argues that investigating the ordinary does matter in "real" archaeology for many reasons, including formulating research questions, integrating data, collaborative research, and even theory building. The book is dedicated to Kit Wesler, remembered especially for his research and interpretive work at the Mississippian Wickliffe Mounds in western Kentucky. The authors use varied approaches to reveal an everyday perspective on the past, from data-based fictional narratives to artifact "histories," ecological regimes and engineering to chaos theory. These studies run the gamut from site-specific to regional.

The especially enjoyable fictional narratives draw upon not only the authors' breadth of knowledge but their imaginations in creating interpretive scenarios that forefront everyday human relationships and activities. Lance Greene, Kandace Hollenbach and Stephen Carmody, Ashley Dumas, and Renee Walker employ narratives as part of explorations of a postremoval Cherokee town, Early Archaic foragers in the MidSouth, salt extraction by Mississippian farmers in south Alabama, and the life of an Archaic dog with his human "family," respectively. These authors note that creating narratives forced them to think through the details of who, what, when, and how things were done, resulting in new research questions.

Two chapters consider human-deer relations. Shane Miller and Jesse Tune investigate Paleoindian hunting practices that exploited deer stranded during river floods in middle Tennessee. Everyday decisions to kill many available deer possibly had the longterm effect of decreasing the deer population during the Younger Dryas. Christopher Moore and Richard Jefferies examine Middle Archaic deer hunting and use in the Ohio River valley. They review the many contexts in which deer were daily components of life, including clothing, ornaments, containers, food, and tools. The physical presence of deer and preparations for hunting them, including magic and rituals, also likely were a part of everyday human interactions.

Artifacts and their use trajectories are another path for accessing the everyday past. Asa Randall and Zackary Gilmore follow the "itineraries" of Late Archaic containers in Florida's St. Johns River region, highlighting possible uses, the shift in technology from shell to pottery, and the everyday work of creating these artifacts. Philip Carr and Andrew Bradbury advocate an Organization of Technology model for aligning the life cycles of stone tools and activities. Ethnographic and ethnohistorical accounts, and special preservation conditions, provide fodder for analyses and interpretations. 